Article

\title{
Sustainable Soil-Compacted Blocks Containing Blast Furnace Slag (BFS) Activated with Olive Stone BIOMASS Ash (OBA)
}

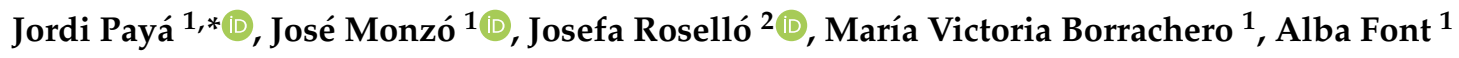 \\ and Lourdes Soriano ${ }^{1}$ \\ 1 Grupo de Investigación en Química de los Materiales (GIQUIMA), Instituto de Ciencia y Tecnología del \\ Hormigón (ICITECH), Universitat Politècnica de València (UPV), 46022 Valencia, Spain; \\ jmmonzo@cst.upv.es (J.M.); vborrachero@cst.upv.es (M.V.B.); alprefon@upvnet.upv.es (A.F.); \\ lousomar@upvnet.upv.es (L.S.) \\ 2 Departamento de Ecosistemas Agroforestales, Universitat Politècnica de Valéncia (UPV), \\ 46022 Valencia, Spain; jrosello@upvnet.upv.es \\ * Correspondence: jjpaya@cst.upv.es
}

Received: 29 October 2020; Accepted: 23 November 2020; Published: 24 November 2020

\begin{abstract}
Soil stabilization using cementing materials is a well-known procedure for earth-based building blocks preparation. For the selected binding materials, innovation usually focuses on low carbon systems, many of which are based on alkaline activation. In the present paper, blast furnace slag (BFS) is used as a mineral precursor, and the innovative alkali activator was olive stone biomass ash (OBA). This means that the most important component in $\mathrm{CO}_{2}$ emissions terms, which is the alkali activator, has been replaced with a greener alternative: OBA. The OBA/BFS mixture was used to prepare compacted dolomitic soil blocks. These specimens were mechanically characterized by compression, and water strength coefficient and water absorption were assessed. The microstructure of blocks and the formation of cementing hydrates were analyzed by field emission scanning electron microscopy and thermogravimetry, respectively. The final compressive strength of the 120-day cured blocks was 27.8 MPa. It was concluded that OBA is a sustainable alkali activator alternative for producing BFS-stabilized soil-compacted blocks: $\mathrm{CO}_{2}$ emissions were $3.3 \mathrm{kgCO}_{2} /$ ton of stabilized soil, which is $96 \%$ less than that for ordinary Portland cement (OPC) stabilization.
\end{abstract}

Keywords: compressive strength; microstructure; water absorption; soil stabilization; FESEM; waterproofing behavior; thermogravimetry

\section{Introduction}

Fabrication of earth blocks and soil stabilization are procedures in which ordinary Portland cement (OPC) is normally used as a cementing component [1]. Despite the low OPC proportion added to soil (5-10\%), the consumption of this cement type has major environmental consequences: the cement industry is responsible for more than $7 \%$ of global $\mathrm{CO}_{2}$ emissions and $12-15 \%$ of the total energy consumed by industrial activities worldwide [2]. In some cases, supplementary cementing materials have been added to enhance soil stabilization: Basha et al. [3] demonstrated that the addition of rice husk ash (RHA) to OPC increases the compressive strength of stabilized soil. Additions of $6 \%$ of RHA and $8 \%$ of OPC yielded 18-25-fold compressive soil strength [4]. The use of pozzolans, such as RHA, reduced the $\mathrm{CO}_{2}$ emissions associated with the binder, although this value is still very high.

In recent years, special focus has been placed on developing new binders with a lower environmental impact [5]. Alkali-activated cements (AACs) are promising substitutes for OPC. These new cements are prepared by mixing a precursor (Al-Si- or Ca-Al-Si-based mineral admixtures, such as 
fly ash, metakaolin or blast furnace slag) and a highly concentrated alkaline solution (sodium/potassium carbonates, hydroxides and silicates). Blast furnace slag (BFS) activation is a very interesting proposal because this precursor requires a small amount of chemical activator and it performs very well mechanically [6]. It is worth noting that these chemical activators are normally synthetic products, and high $\mathrm{CO}_{2}$ emissions are associated with their production.

Some interesting data have been reported on replacing these chemical activators with alternative and more sustainable by-products or waste. For instance, alkali silicates $\left(\mathrm{K}_{2} \mathrm{SiO}_{3}, \mathrm{Na}_{2} \mathrm{SiO}_{3}\right)$ have been replaced with mixtures of $\mathrm{KOH}$ or $\mathrm{NaOH}$ and biomass ashes like RHA [7,8], sugarcane bagasse ash [9], sugarcane straw ash [10], or industrial waste, such as spent diatomite from the wine and beer industries [11], glass waste [12] or soda residue from ammonia soda process for $\mathrm{Na}_{2} \mathrm{CO}_{3}$ synthesis $[13,14]$. Very recently, some examples of AACs have been reported in which no commercial reagents are used. For instance, high-calcium content wood ash $\left(61 \% \mathrm{CaO}, 12 \% \mathrm{~K}_{2} \mathrm{O}\right)$ activates coal fly ashes [15]. Peys et al. [16] reported alkaline ashes $\left(30 \% \mathrm{~K}_{2} \mathrm{O}\right)$ from stalk and cob corn for activating metakaolin. Soriano et al. [17] demonstrated the feasibility of preparing alkali-activated BFS by adding almond-shell biomass ash.

Soil has been used for several thousands of years as a construction material and is still widely used today, especially in developing countries. Using soil as raw material in construction has several advantages: recyclability, no toxicity, no pollution, low energy use in manufacturing, cheaper than other alternatives and local production (avoiding transport), good hygrothermal behavior, among others [1]. Obviously, there are some facts that limit its use: few specific regulations, low level of training for engineers, very intensive labor technique during the construction process, seismic behavior, durability in wet climates, and water erosion, among others.

Addition of OPC to soil enhances some properties of stabilized soil blocks, mainly strength and durability. Alternatives are being proposed that employ alkali-activated cement: a significant number of reports/papers have been published in which BFS and coal fly ash were used as precursors. In many cases, the activating solution is highly concentrated: $3-18 \mathrm{M} \mathrm{NaOH}$ solution for activating precursors [18]. This has one major consequence from the sustainability point of view: the consumption of reagents and their carbon footprint. It has been reported [19] that employing $\mathrm{NaOH}$ in $\mathrm{BFS}$ activation is more sustainable than Portland cement for soil stabilization ( $23 \%$ less $\mathrm{CO}_{2}$ emissions).

The aim of this research is to use an alternative and more sustainable activator to prepare soilcompacted blocks: the selected activator is the olive stone biomass ash (OBA). This waste, which derives from the combustion of olive stones, has been tested previously in BFS activation, and very good results were obtained in the strength and microstructure development of OBA/BFS mortars [20-22]. The chemical composition of OBA presents high proportions of $\mathrm{CaO}$ and $\mathrm{K}_{2} \mathrm{O}$, and it has been reported [21] that the compressive strength for $4 \mathrm{M} \mathrm{NaOH}$-activated BFS is equivalent to the $15.8 \%$ replacement of BFS with OBA.

In this research, the preparation of dolomitic soil blocks and the mechanical, chemical, physical, microstructural and waterproofing characterization were carried out by comparing OPC and OBA/BFS soil-compacted blocks. The OBA/BFS blocks yielded excellent performance as regards to mechanical, waterproofing and environmental characteristics.

\section{Materials and Methods}

Soil was dolomitic in nature and was supplied by Pavasal Company (Quart de Poblet, Spain). This soil was dried at $105^{\circ} \mathrm{C}$ for $48 \mathrm{~h}$ before being used. The main mineral phases were dolomite and calcite, and the minor components were quartz and muscovite. The largest particle size was $4 \mathrm{~mm}$, and it had a granulometric distribution (\% passing), as shown in Figure 1a. The blast furnace slag (BFS) was supplied by Cementval (Puerto de Sagunto, Spain). It was ground in a laboratory mill for $30 \mathrm{~min}$, its mean particle size was $26.0 \mu \mathrm{m}$ and Figure $1 \mathrm{~b}$ shows its granulometric distribution. Chemical composition of BFS is summarized in Table 1. Olive stone (OS) was supplied by Sahuco Aceites S.L. (La Gineta-Albacete, Spain). This sample was dried at $105^{\circ} \mathrm{C}$ for $48 \mathrm{~h}$. Olive stone biomass 
ash (OBA) was supplied by Almazara Candela (Elche, Spain). Ash was dried at $105^{\circ} \mathrm{C}$ for $48 \mathrm{~h}$ and then ground in a laboratory mill for $10 \mathrm{~min}$. The mean particle size was $22.7 \mu \mathrm{m}$ and Figure 1c shows its particle distribution.

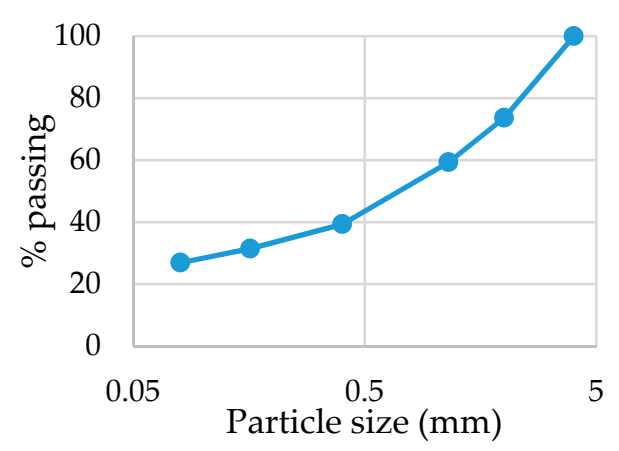

(a)

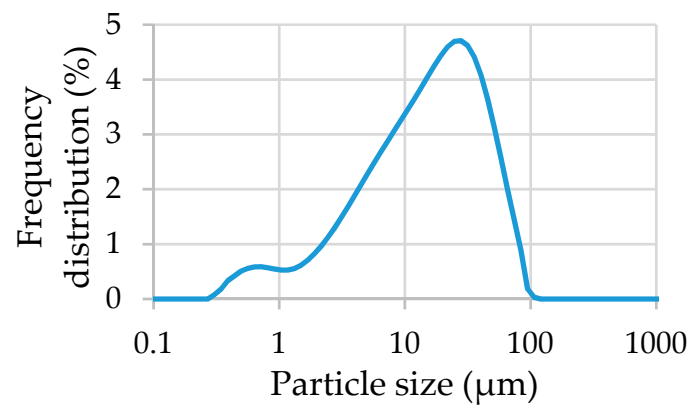

(c)

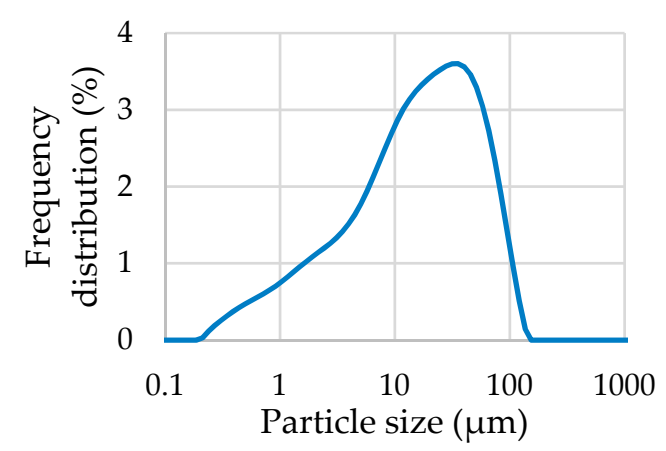

(b)

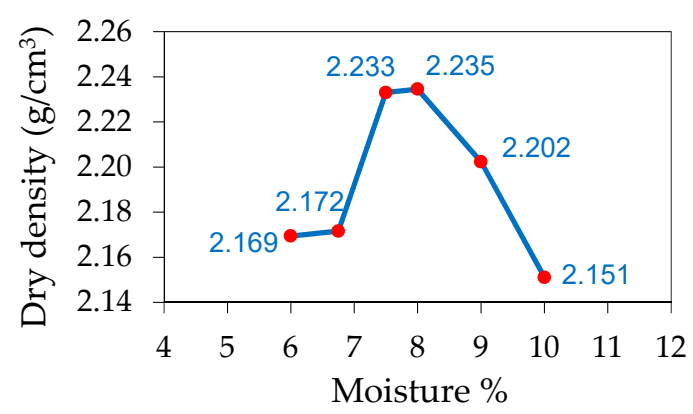

(d)

Figure 1. (a) Size distribution (by sieving) for dolomitic soil; (b) Particle distribution (by laser granulometry in water) for blast furnace slag (BFS); (c) Particle distribution (by laser granulometry in water) for olive stone biomass ash (OBA); (d) dry density curve for the soil/BFS/OBA mixture vs. moisture.

Table 1. Chemical composition of BFS.

\begin{tabular}{cc}
\hline Oxide & \% by Mass \\
\hline $\mathrm{Na}_{2} \mathrm{O}$ & 0.87 \\
$\mathrm{MgO}$ & 7.43 \\
$\mathrm{Al}_{2} \mathrm{O}_{3}$ & 10.55 \\
$\mathrm{SiO}_{2}$ & 30.53 \\
$\mathrm{P}_{2} \mathrm{O}_{5}$ & 0.26 \\
$\mathrm{SO}_{3}$ & 1.93 \\
$\mathrm{~K}_{2} \mathrm{O}$ & 0.57 \\
$\mathrm{CaO}$ & 40.15 \\
$\mathrm{Fe}_{2} \mathrm{O}_{3}$ & 1.29 \\
$\mathrm{LOI}$ & 5.53 \\
\hline
\end{tabular}

The binder (BFS+OBA) had the proportion summarized in Table 2. The amount of water in the mixed soil was determined by means of the mini Harvard modified proctor (ASTM STP479, [23]) and in accordance with Spanish standard UNE 103501 [24] (compaction energy $2632 \mathrm{~J} / \mathrm{cm}^{3}$ ). The maximum dry density of the mixture was obtained for ca. $8 \%$ of moisture, as Figure $1 \mathrm{~d}$ shows. 
Table 2. Composition of the soil-compacted blocks.

\begin{tabular}{cc}
\hline Component & Value \\
\hline Soil & $1000 \mathrm{~g}$ \\
OBA (activator) & $40 \mathrm{~g}$ \\
BFS (precursor) & $100 \mathrm{~g}$ \\
Water & $91 \mathrm{~g}$ \\
Water/solid ratio & 0.0798 \\
Activator/precursor ratio & 0.4 \\
\hline
\end{tabular}

The mixing procedure was followed by using a mortar mixer according to UNE-EN 196-1 [25]. The rotation rate of the mixing paddle was $140 \pm 5 \mathrm{rpm}$ and the planetary movement was $62 \pm 5 \mathrm{rpm}$. The steps included: (a) OBA (40 g) and water (91 g) were mixed for $2 \mathrm{~min}$; (b) the BFS (100 g) was added and mixed for $2 \mathrm{~min}$; (c) the soil (1000 g) was added and the mixture was stirred for $3 \mathrm{~min}$.

The final mix was compacted in the mold shown in Figure 2a. The stabilized soil was compacted in three layers by an Army-type hammer (1.5 kg; Figure 2b). The applied energy was $2632 \mathrm{~J} / \mathrm{cm}^{3}$ (19 knocks, $20 \mathrm{~cm}$ high). Cubic samples (40 mm size) were obtained (Figure 2c), coated with a plastic film and stored at room temperature $\left(20-23^{\circ} \mathrm{C}\right)$. Film was withdrawn for the samples tested in compression, samples were left in a laboratory atmosphere for 2 days; for the samples tested in absorption or submerged in water, samples were dried until (laboratory atmosphere) constant weight (ca. 7-10 days). Compressive strength was applied by means of a universal INSTRON model 3382. Samples were tested with a displacement of $1 \mathrm{~mm} / \mathrm{min}$ in an adapted device (Figure 2d). The absorption test was carried out in accordance with UNE 41410 [26]. Submersion in water was performed according to NTC 5324 [27].

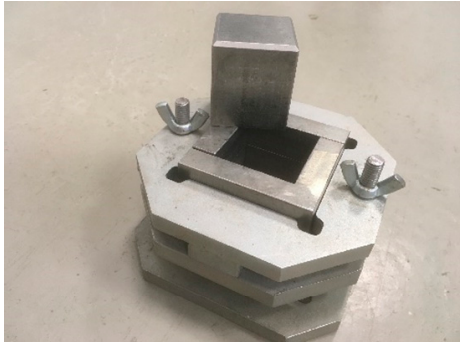

(a)

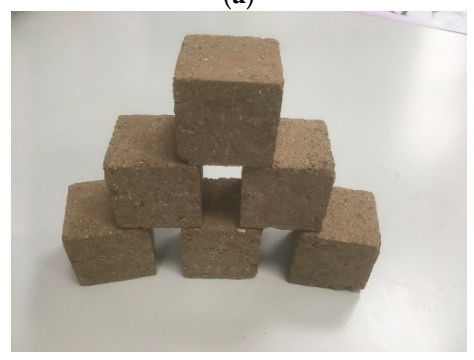

(c)

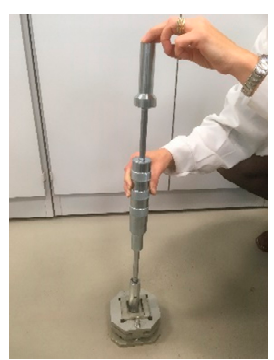

(b)

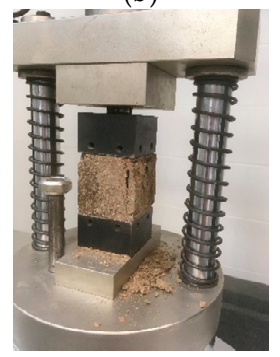

(d)

Figure 2. Preparing and testing blocks: (a) $40 \mathrm{~mm}$-sized cubic mold; (b) Army-type hammer for compacting; (c) Cubic specimens; (d) Device for compression testing.

Microscopic studies were carried out by field emission scanning electron microscopy (FESEM) in a ZEISS Supra 55 equipment. The stabilized soil samples were carbon-coated and observed using 2 $\mathrm{kV}$. Energy dispersive spectroscopy (EDS) analyses were carried out with an extra tension of $15 \mathrm{kV}$ (working distance of 6-8 mm). Thermogravimetric studies were done with a Mettler-Toledo 850 ultrabalance: the $65^{\circ} \mathrm{C}$ dried samples were placed inside aluminum crucibles (sealed with pin-holed lids). A heating rate of $10^{\circ} \mathrm{C} / \mathrm{min}$ with an air flow of $75 \mathrm{~mL} / \mathrm{min}$ were the conditions established for the thermogravimetric test. 


\section{Results and Discussion}

\subsection{Olive Stone (OS) Biomass: Starting Raw Material}

During olive oil production, olives are crushed to extract liquid [28]. The olive stone is the fruit endocarp (innermost part) and encloses the seed. After different processes in which olive pulp is removed, small dry pieces of OS are obtained [29], as in Figure 3a. The organic-based waste is usually valued by combustion because it has high calorific power [30]. Figure 3b shows the FESEM micrographs of this endocarp, a hard and woody tissue composed of sclereids. These cells, also known as stone cells, come from the sclerenchyma and are lignified. This means that most of the material is organic in nature. When OS were calcined at $600{ }^{\circ} \mathrm{C}$ for $3 \mathrm{~h}$, the organic material was removed and the reduction in mass exceeded $99 \%$. The remaining ash was $0.77 \%$ compared to the starting dried OS. Figure $3 \mathrm{e}$ shows what the ash prepared by calcination in an oven at $600{ }^{\circ} \mathrm{C}$ looks like and Figure $3 \mathrm{f}$ depicts a micrograph of ash.

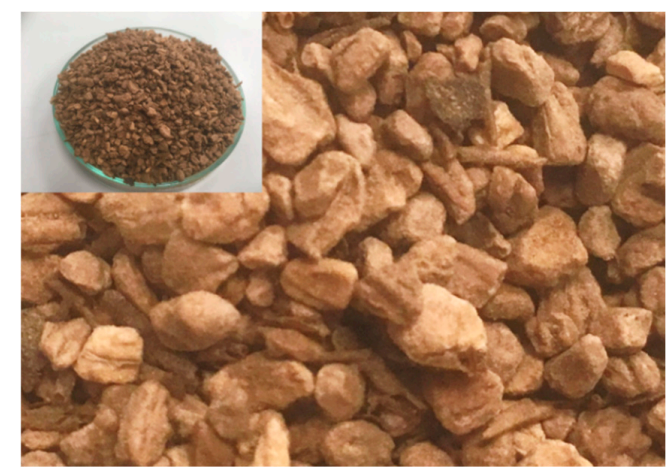

(a)

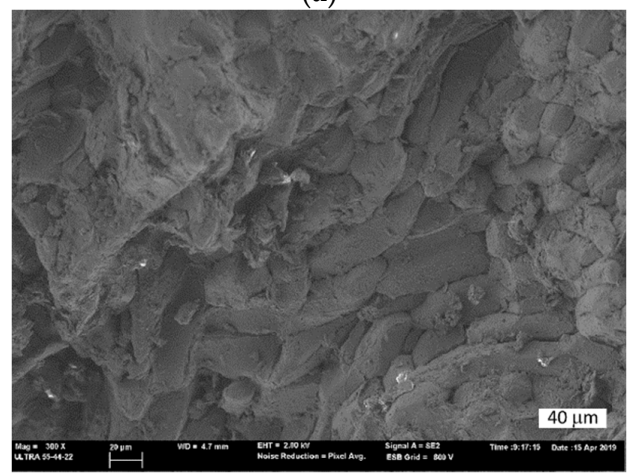

(c)

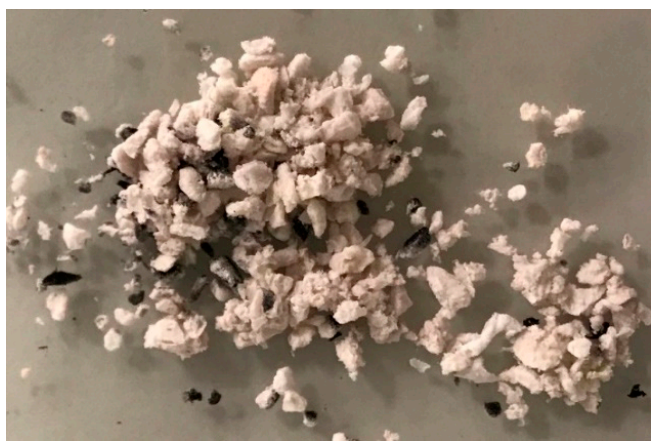

(e)

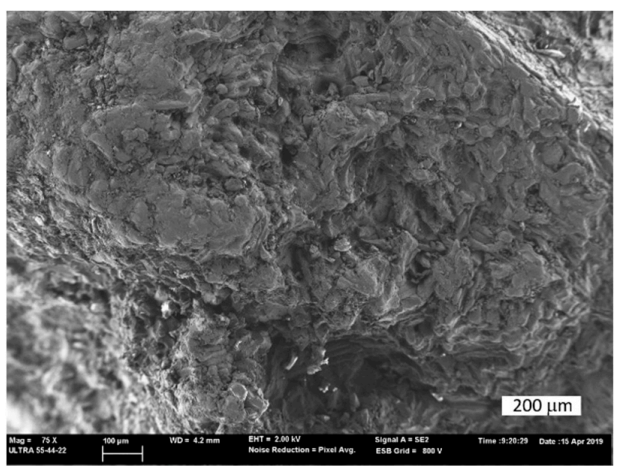

(b)

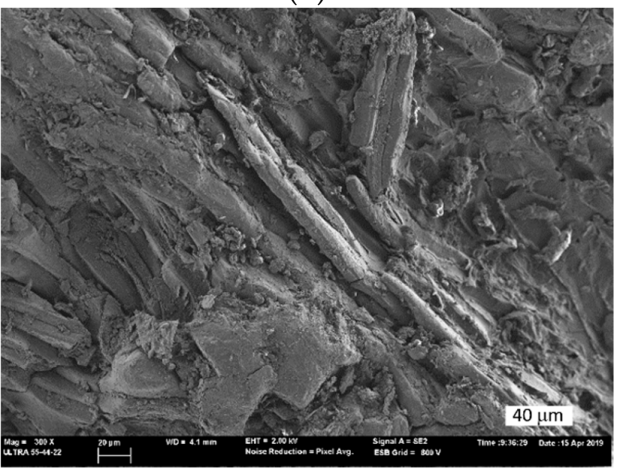

(d)

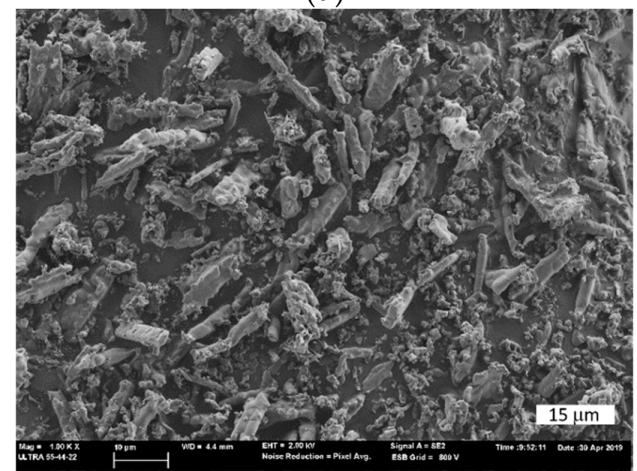

(f)

Figure 3. Olive stone biomass: (a) Photograph of crushed particles; (b-d) FESEM micrographs of the sclereids in olive stones; (e) Remaining ash after calcination at $600{ }^{\circ} \mathrm{C}$ for $3 \mathrm{~h}$; (f) FESEM micrograph of the remaining ash $(\times 1000)$. 


\subsection{Characteristics of the Olive Stone Biomass Ash (OBA)}

Figure 4 shows four FESEM micrographs of OBA. The morphology of particles was very irregular. The diameter of many particles was smaller than $20 \mu \mathrm{m}$ (see Figure $4 \mathrm{a}, \mathrm{b}$ ), which corresponds to the particle distribution of OBA (Figure 1c). Some particles were compacted (Figure 4c), but most were porous and formed by twinned structures (Figure $4 \mathrm{~d}$ ). Chemical composition was analyzed by EDS. Chemical composition (see Table 3 ) is based principally on calcium and potassium, and both elements are alkaline in nature. The sum of both $\left(\mathrm{K}_{2} \mathrm{O}+\mathrm{CaO}\right)$ reached $75 \%$, which indicates that this ash will show alkalinity when mixed in water. In fact, when OBA was dispersed in water, $\mathrm{pH}$ was higher than 13.

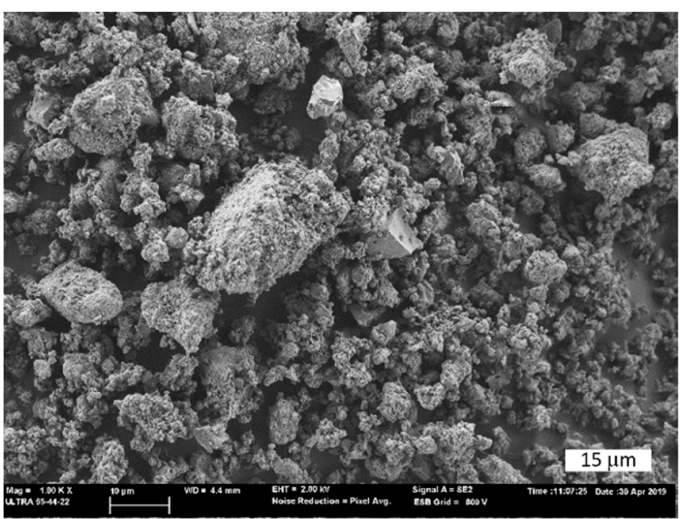

(a)

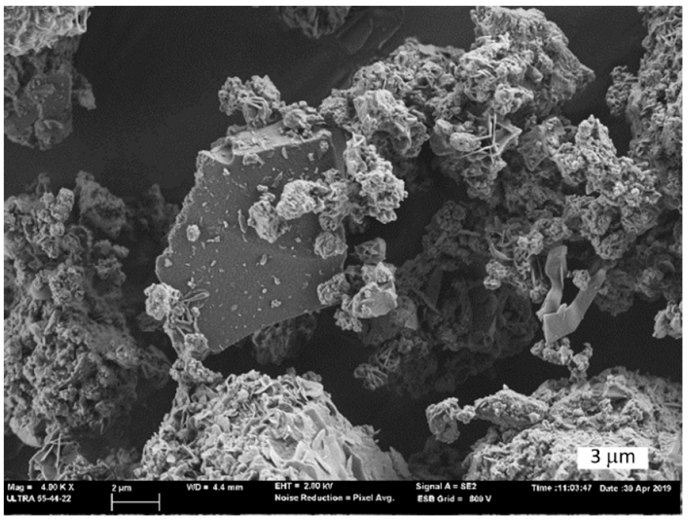

(c)

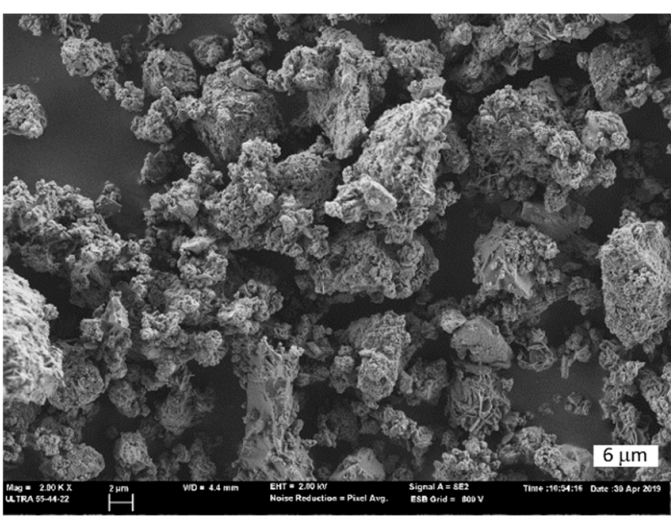

(b)

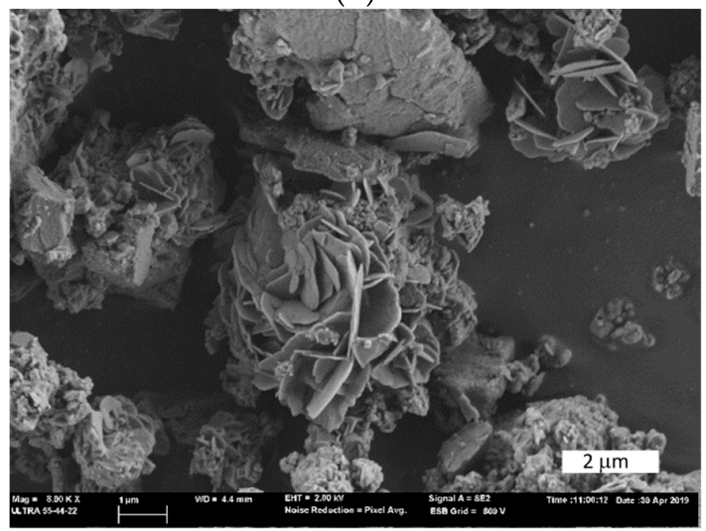

(d)

Figure 4. FESEM micrographs of OBA: (a) A general view, $\times 1000$; (b) A general view, $\times 2000$; (c) Detail of dense particle $(\times 4000)$; (d) Detail of porous particle $(\times 8000)$.

Table 3. Chemical composition* of OBA (by EDS, mean values from eight data).

\begin{tabular}{ccc}
\hline Oxide & \% by Mass & Std. Dev \\
\hline $\mathrm{Na}_{2} \mathrm{O}$ & 1.11 & 0.12 \\
$\mathrm{MgO}$ & 7.77 & 1.06 \\
$\mathrm{Al}_{2} \mathrm{O}_{3}$ & 0.99 & 0.25 \\
$\mathrm{SiO}_{2}$ & 5.38 & 1.97 \\
$\mathrm{P}_{2} \mathrm{O}_{5}$ & 3.54 & 0.59 \\
$\mathrm{SO}_{3}$ & 1.68 & 0.77 \\
$\mathrm{Cl}$ & 0.73 & 0.34 \\
$\mathrm{~K}_{2} \mathrm{O}$ & 43.41 & 2.62 \\
$\mathrm{CaO}$ & 32.46 & 2.79 \\
$\mathrm{FeO}$ & 2.94 & 1.14
\end{tabular}

* These values were calculated based on the calcined sample (loss on ignition was $18.9 \%$ ). 


\subsection{Mechanical Properties of Soil-Compacted Blocks}

The compacted blocks containing OBA were cured after demolding and sealed with plastic film. The previous tests carried out demonstrated that if cubic specimens were left under laboratory conditions (ca. temperature $22-25^{\circ} \mathrm{C}$ and $\mathrm{RH} 40-60 \%$ ), most of the water used in the mixture would evaporate, which would imply that cementing gel development would not be optimum. Apparently, the reaction rate of OBA and BFS was low, and water evaporation must be minimized to complete the alkali activation of the precursor. Specimens were cured for 7, 28 and 120 days. The density of specimens after removing plastic film was $2364 \pm 33 \mathrm{~kg} / \mathrm{m}^{3}$ (mean value of 18 specimens). Cubes were left in a laboratory atmosphere for 2 days and water evaporation took place: density reduced by $2.66 \%$ $\left(2301 \pm 35 \mathrm{~kg} / \mathrm{m}^{3}\right)$. After this process, cubes were tested in compression (Rc values, in $\mathrm{MPa}$ ).

After 7 curing days, Rc was $12.5 \pm 1.3 \mathrm{MPa}$ : this is a very high value and such behavior was attributed initially to the high-energy compacting process. Under the same conditions, soil was compacted with no cementing component [31] and strength went below $3 \mathrm{MPa}$. This means that the reaction between OBA and BFS was effective in cementing contribution terms. For comparison purposes, the soil/OPC samples (1000 $\mathrm{g}$ of soil, $100 \mathrm{~g}$ of CEM I 42.5R and $97 \mathrm{~g}$ of water) were prepared. This sample type showed [31] a strength of $14 \mathrm{MPa}$. This means that the reaction for OPC was faster and more effective than the alkaline reaction of BFS with OBA. After 28 curing days, the Rc of the OBA/BFS blocks was $18.5 \pm 2.0 \mathrm{MPa}$, a significantly lower value than that obtained [31] for the OPC-stabilized block (24 MPa). However, for longer curing times (120 days), the Rc for the OBA/BFS system was $27.8 \pm 1.9 \mathrm{MPa}$. This behavior showed very good development of the cementing gel structure over a long curing age. Figure 5 illustrates the strength development trend for the OBA/BFS cubic specimens.

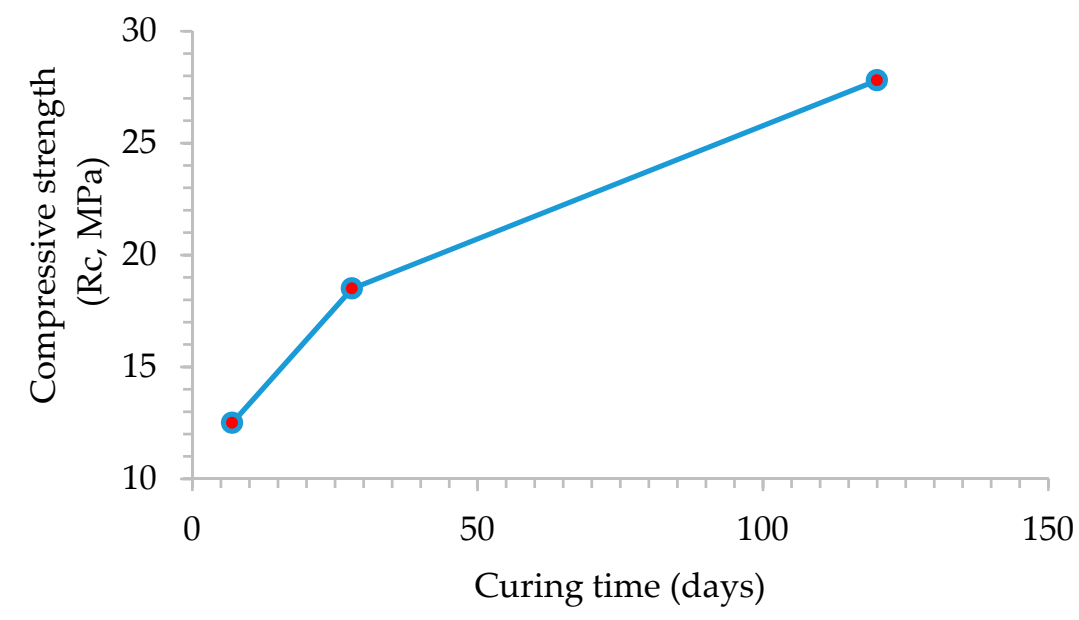

Figure 5. Compressive strength development of the OBA/BFS soil-compacted cubes.

\subsection{Characterization of Cementing Gel}

The stabilized soil was characterized by means of the thermogravimetric analysis. Figure 6 depicts the derivative thermogravimetric curves (DTG) for the 28-day and 120-day cured soil-compacted samples. We can observe several peaks on these DTG curves. The observed mass losses correspond to dehydration/dehydroxilation/decarbonation processes [20,32]. The formation of cementing gels is revealed by the dehydration of C-S-H and C-A-S-H $\left(\approx 130-160^{\circ} \mathrm{C}\right)$ and their dehydroxylation $(\approx 230-300$ ${ }^{\circ} \mathrm{C}$ ). Minor peaks are seen in other zones, which are attributed to the decomposition of hydrotalcite, a cementing compound that usually forms by the alkali activation of BFS [33]. The mass loss observed at the higher temperature of $500{ }^{\circ} \mathrm{C}$ was due to dolomite decarbonation (release of $\mathrm{CO}_{2}$ ) beginning [34]. The mass loss within the $35-600^{\circ} \mathrm{C}$ range observed for samples was small because most was dolomite. The TG data are summarized in Table 4. The total mass losses were $3.97 \%$ for the 28 -day sample and $4.49 \%$ for the 120 -day one. Interestingly, the mass loss for the $35-200{ }^{\circ} \mathrm{C}$ and $200-400{ }^{\circ} \mathrm{C}$ ranges 
was greater for the 120-day cured sample, which suggests an increase in the cementing gel with the chemical reaction.

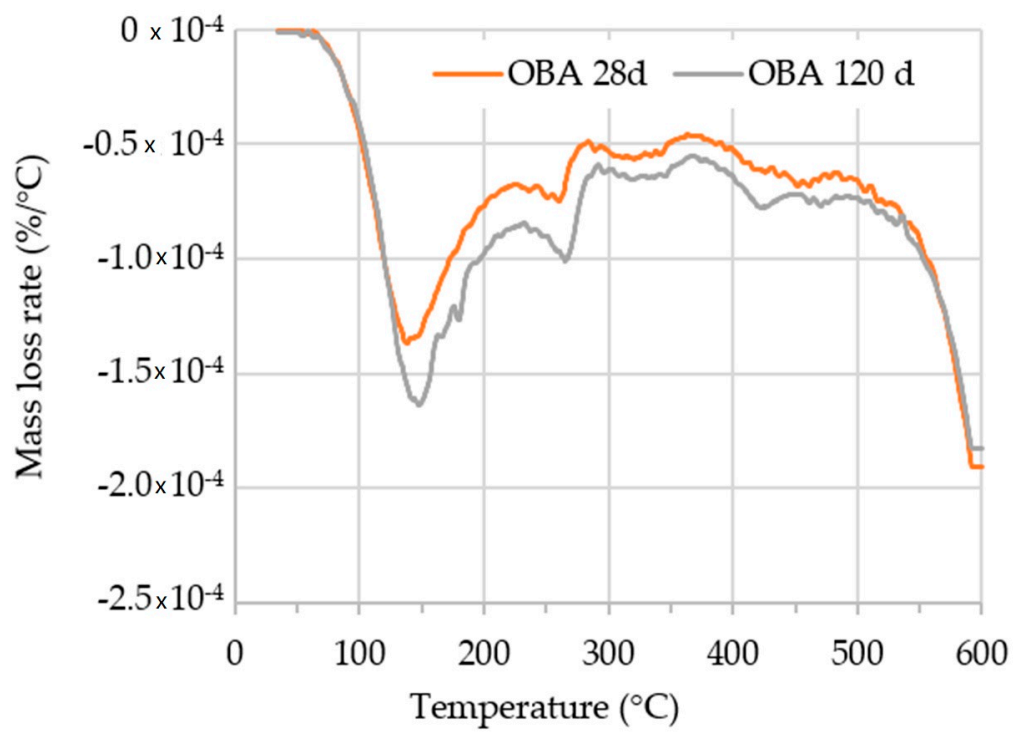

Figure 6. Derivative thermogravimetric curves (DTG) for the OBA/BFS soil-compacted samples after 28 and 120 curing days.

Table 4. Thermogravimetric data for the OBA/BFS soil-compacted samples after 28 and 120 curing days.

\begin{tabular}{cccc}
\hline & \multicolumn{3}{c}{ Mass Loss $(\mathbf{\%})$} \\
\hline Curing Time & $\mathbf{3 5 - 2 0 0}{ }^{\circ} \mathbf{C}$ & $\mathbf{2 0 0 - 4 0 0}{ }^{\circ} \mathbf{C}$ & $\mathbf{3 5 - 6 0 0}{ }^{\circ} \mathbf{C}$ \\
\hline 28 days & 1.09 & 2.25 & 3.97 \\
120 days & 1.20 & 2.65 & 4.49 \\
\hline
\end{tabular}

The FESEM studies were carried out to confirm the formation of cementing gels and EDS analysis data were summarized in Table 5. Figure 7 shows the selected micrographs of the OBA/BFS soil-compacted blocks after 28 curing days. Figure 7a,b depict general views of soil particles (dolomite and calcite), surrounded by cementing gel. These phases were characterized by the EDS analysis (see Figure 7a). The calcite particle had $82.5 \% \mathrm{CaO}$, the dolomite particle had $60.2 \% \mathrm{CaO}$ and $35.7 \% \mathrm{MgO}$ ), and gels $\mathrm{Ga}$ and $\mathrm{Gb}$ had the following compositions of the main elements: for $\mathrm{Ga}, \mathrm{Al}_{2} \mathrm{O}_{3}=14.6 \%$, $\mathrm{SiO}_{2}=28.6 \%, \mathrm{CaO}=38.6 \%, \mathrm{~K}_{2} \mathrm{O}=6.31 \%$ and $\mathrm{MgO}=7.8 \%$; for $\mathrm{Gb}, \mathrm{Al}_{2} \mathrm{O}_{3}=16.4 \%, \mathrm{SiO}_{2}=35.4 \%$, $\mathrm{CaO}=26.0 \%, \mathrm{~K}_{2} \mathrm{O}=9.8 \%$ and $\mathrm{MgO}=3.8$. These compositions agree with the presence of gel $\mathrm{C}(\mathrm{K})-\mathrm{A}-\mathrm{S}-\mathrm{H}$, similarly, to gel C(N)-A-S-H [35].

Table 5. Chemical composition (in mass \%, from EDS analysis) of the cementing hydrates and aggregate particles observed in FESEM micrographs.

\begin{tabular}{cccccccccc}
\hline Figure & Spot & $\mathbf{C a O}$ & $\mathbf{M g O}$ & $\mathbf{S i O}_{\mathbf{2}}$ & $\mathbf{A l}_{\mathbf{2}} \mathbf{O}_{\mathbf{3}}$ & $\mathbf{K}_{\mathbf{2}} \mathbf{O}$ & $\mathbf{F e}_{\mathbf{2}} \mathbf{O}_{\mathbf{3}}$ & $\mathbf{P}_{\mathbf{2}} \mathbf{O}_{\mathbf{5}}$ & $\mathbf{S O}_{\mathbf{3}}$ \\
\hline Figure 7a & $\mathrm{C}$ & 82.50 & 3.43 & 6.86 & 3.97 & 2.14 & 1.10 & 0.00 & 0.00 \\
Figure 7a & $\mathrm{D}$ & 60.20 & 35.70 & 1.73 & 0.88 & 0.49 & 1.00 & 0.00 & 0.00 \\
Figure 7a & $\mathrm{Ga}$ & 38.6 & 7.8 & 28.6 & 14.6 & 6.31 & 1.97 & 0.58 & 1.14 \\
Figure 7a & $\mathrm{Gb}$ & 26.00 & 3.80 & 35.20 & 16.40 & 9.80 & 6.61 & 0.00 & 0.81 \\
Figure 8a & Several & $28.7-35.7$ & $19.5-27.0$ & $13.7-20.7$ & $17.5-20.2$ & $4.8-7.4$ & $0.0-3.5$ & $0.0-0.6$ & $0.0-0.9$ \\
Figure 8d & Several & $13.3-17.2$ & $29.8-34.2$ & $15.2-15.3$ & $21.3-23.9$ & $6.8-8.0$ & $1.2-2.9$ & 0.00 & $1.8-2.5$ \\
\hline
\end{tabular}




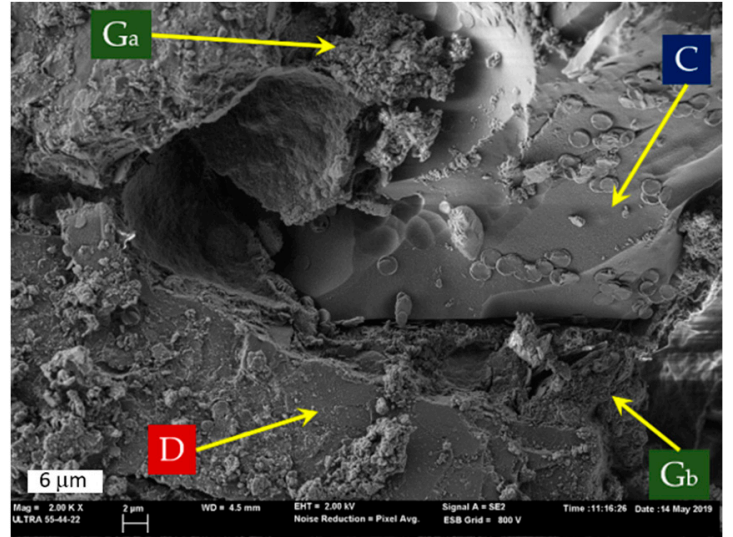

(a)

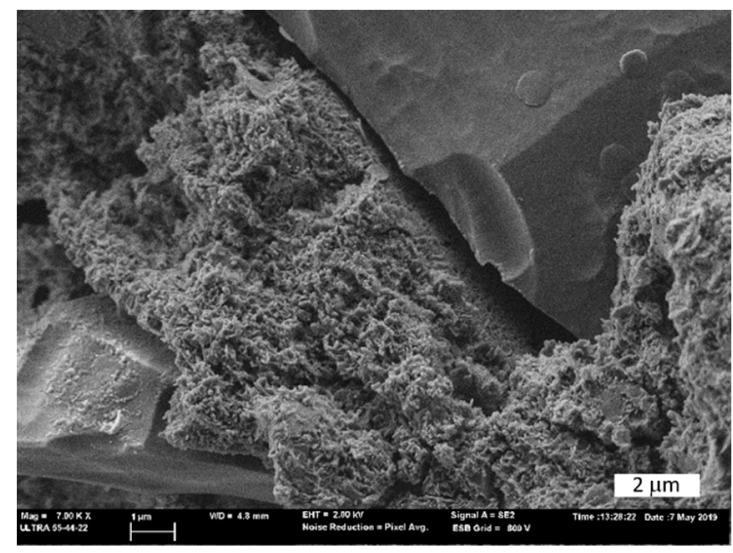

(b)

Figure 7. FESEM micrographs of the OBA/BFS soil-compacted sample after 28 curing days: (a) $\times 2000$; (b) $\times 7000$. Key: C: calcite; D: dolomite; Ga and Gb: cementing gel.

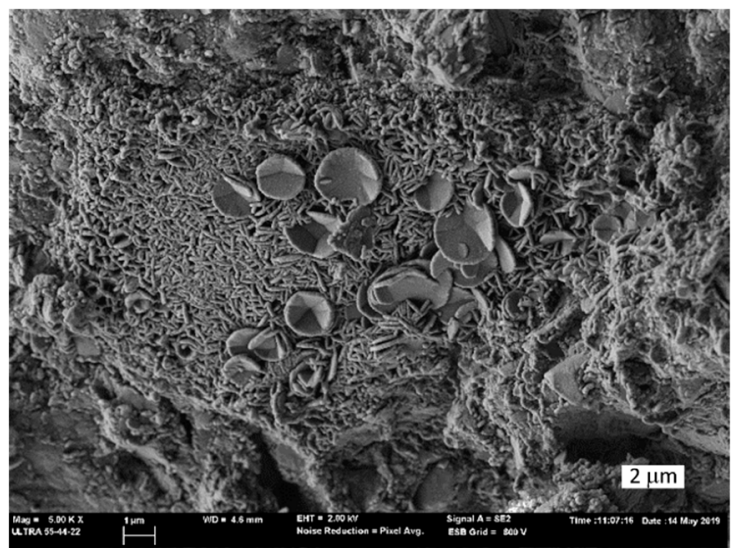

(a)

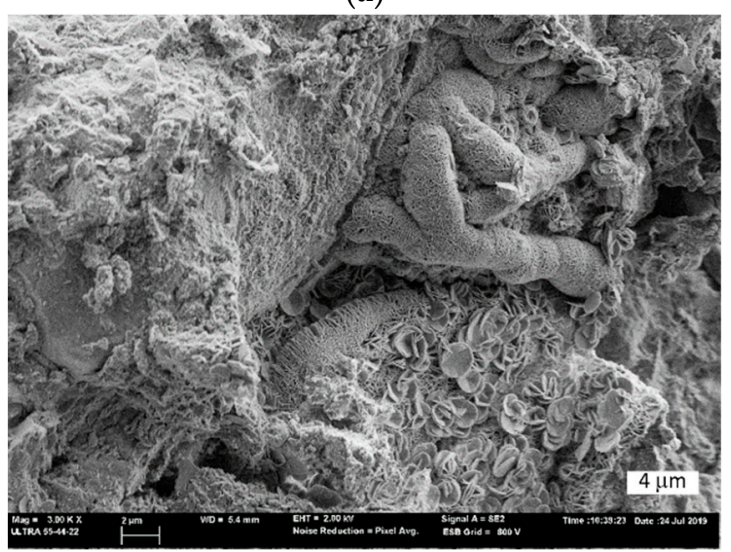

(c)

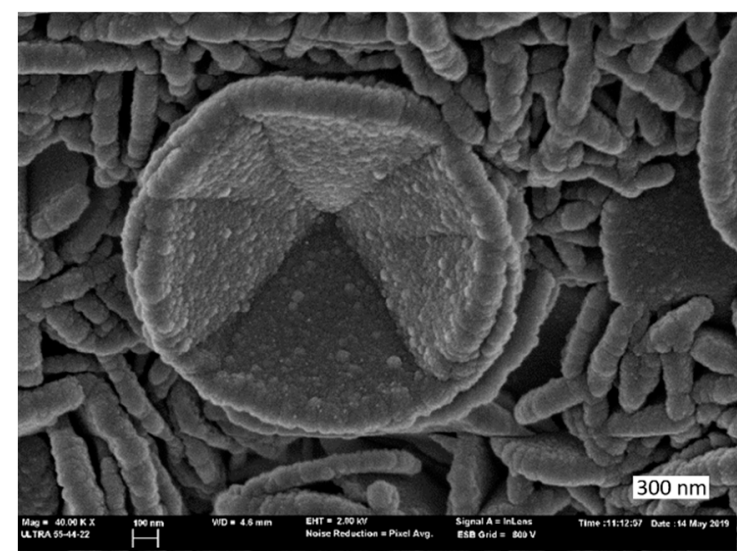

(b)

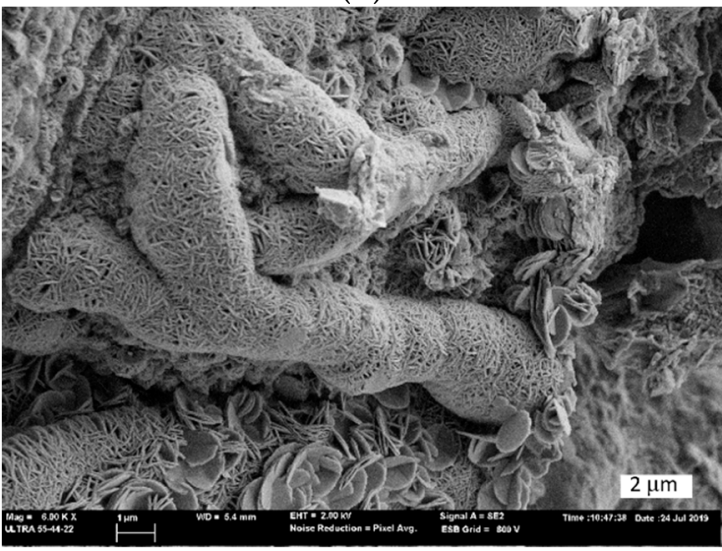

(d)

Figure 8. FESEM micrographs of the gel in the OBA/BFS soil-compacted sample after 28 curing days:

(a) $\times 5000 ;$ (b) $\times 40,000 ;$ (c) $\times 3000 ;(d) \times 6000$.

Figure 8 shows some detailed views of the microstructures of the cementing gel. Figure $8 \mathrm{a}, \mathrm{b}$ depict that the gel is composed of $1 \mu \mathrm{m}$-diameter discs surrounded by twinned discs. A more detailed EDS analysis (spots) of these gels revealed that the composition contained a significant amount of magnesium. BFS usually contains a moderate quantity of magnesium, and this element is found in the cementing gel after BFS alkali activation [36]. It has been reported that limestone is dissolved during its alkali activation by means of $\mathrm{NaOH}$ and $\mathrm{NaOH} /$ waterglass [37]. Thus, in the cementing gel 
observed in Figure 8a, a significant quantity of magnesium is probably attributed to its dissolution from dolomite and its inclusion in the gel as the $\mathrm{C}(\mathrm{K}, \mathrm{M})-\mathrm{A}-\mathrm{S}-\mathrm{H}$ product. The chemical composition of the gel ranged as follows: $\mathrm{MgO}=19.5-27.0 \%, \mathrm{Al}_{2} \mathrm{O}_{3}=17.5-20.2 \%, \mathrm{SiO}_{2}=13.7-20.7 \%, \mathrm{~K}_{2} \mathrm{O}=4.8-7.4 \%$ and $\mathrm{CaO}=28.7-35.7 \%$. Figure $8 \mathrm{c}$ shows two different microstructures of the gel: the previously described one and a new one. This new gel is worm-like (Figure 8d). Its chemical composition (EDS spots) showed that it presented a higher proportion of magnesium: $\mathrm{MgO}=29.8-34.2 \%, \mathrm{Al}_{2} \mathrm{O}_{3}=21.3-23.9 \%$, $\mathrm{SiO}_{2}=15.2-15.3 \%, \mathrm{~K}_{2} \mathrm{O}=6.8-8.0 \%$ and $\mathrm{CaO}=13.3-17.2 \%$. In this case, the quantity of $\mathrm{MgO}$ was notably higher than $\mathrm{CaO}$, which suggests that this gel preferably forms when dolomite dissolution is considerable.

\subsection{Behavior of the OBA/BFS Soil-Compacted Blocks in a Humid Environment}

The durability of the soil stabilized blocks is usually assessed by partially or completely soaking in water, capillary absorption, wet-drying and freeze-thawing procedures, among others [38]. In our study, capillary absorption (according to UNE 41410 [26]), total water absorption (by immersion in water for 2 and $72 \mathrm{~h}$ [27]) and the water strength coefficient (ratio between the dry state compressive strength and the water-soaked compressive strength [39]) were determined. These parameters were tested with the 28-day cured cubes.

Figure 9 shows the mass gain (in g) in the capillary absorption test carried out for $320 \mathrm{~min}$. Data (mean value of 3 specimens) for the OBA/BFS and OPC-stabilized blocks were depicted. It is highlighted that the capillary absorption coefficient for the OBA/BFS sample $\left(0.048 \pm 0.014 \mathrm{~g} \cdot \mathrm{cm}^{-2} \cdot \mathrm{min}^{-0.5}\right)$ was higher than for that of the OPC sample $\left(0.032 \pm 0.005 \mathrm{~g} \cdot \mathrm{cm}^{-2} \cdot \mathrm{min}^{-0.5}\right)$. This means that the connection among capillary pores was more marked when OBA/BFS was used as a binder. Thus more restrictions in its use must be taken into account in order to protect these types of blocks from external environmental conditions.

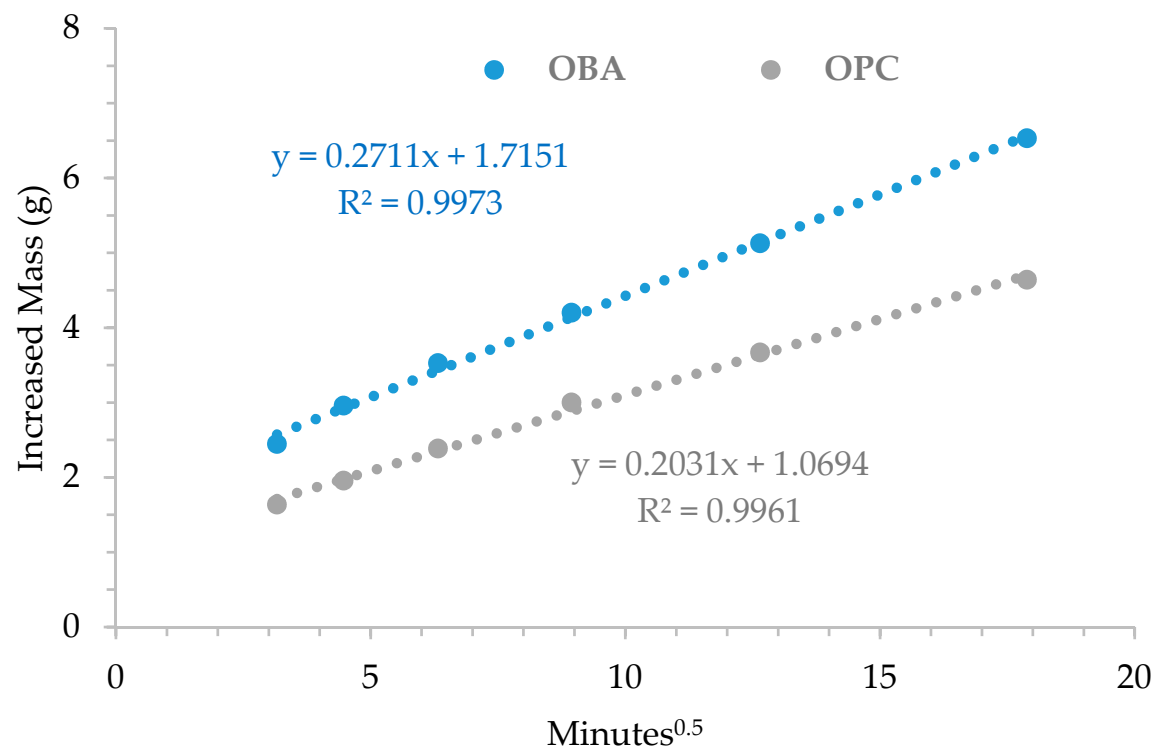

Figure 9. Capillary absorption curves for the OBA/BFS and OPC soil-compacted blocks and fitting equations.

After soaking in water, the OBA/BFS cubes showed a low increase in mass (5.77 $\pm 0.34 \%$ after $1 \mathrm{~h} ; 5.79 \pm 0.32 \%$ after $2 \mathrm{~h}$ ). This means that the total porosity was low, which agrees with the strong cementing effect of the OBA/BFS alkali-activated system and the compaction energy while preparing the block. The total water absorption after $24 \mathrm{~h}$ was significantly lower than $15 \%$ (maximum value recommended [40]). After $72 \mathrm{~h}$ of water soaking, the mass only increased to $6.16 \pm 0.30 \%$. Some cubes were tested after $2 \mathrm{~h}$ of soaking, and the compressive strength after soaking was $13.01 \pm 0.62$ $\mathrm{MPa}$. The calculated water strength coefficient $\left(\mathrm{W}_{\mathrm{R}-2 \mathrm{~h}}\right)$ was 0.70 . This result is extremely positive 
because it is similar or higher to previously reported results [40] for 15MPa static-compressed blocks stabilized with different cementing systems ( $8 \%$ cement, $12 \%$ lime, mixtures of $8 \%$ cement and $4 \%$ lime). Some additional cubes were water-soaked for $72 \mathrm{~h}$ and compressive strength was $13.65 \pm 1.18$ $\mathrm{MPa}$, which yielded a water strength coefficient $\mathrm{W}_{\mathrm{R}-72 \mathrm{~h}}$ of 0.74 . This excellent result confirms that the cementing gel is not water soluble and its stability is high despite immersion in water. During the long-term immersion, the alkali activation of BFS was probably completed because water was largely available. The binding effect of the formed gel suggests that soil particles strongly adhered despite the extreme environmental conditions.

\subsection{Sustainability and Practical Considerations}

Despite the low percentage of OPC used in soil stabilization, this component has an intense environmental impact, specifically in carbon footprint terms. Replacing OPC with alternative components to increase technical soil performance is a critical aspect to evaluate and test. The use of waste to prepare the stabilizer component makes the final product more sustainable. Salim et al. [41] reported increasing by $65 \%$ the compressive strength of compressed earth bricks vs. non-stabilized earth, by adding up to $10 \%$ of sugarcane bagasse ash. This is good behavior, but the technical performance of the prepared blocks was not excellent, compressive strength was limited after 28 curing days (less than $4 \mathrm{MPa}$ ) and shrinkage cracks were observed in blocks. This result indicates that a more effective binder must be used in stabilization. The development of alkali-activated cements is an interesting alternative because $\mathrm{CO}_{2}$ emissions are sometimes associated with cement, which is significantly lower than that for pure OPC or pozzolan/OPC systems. However, for alkali-activated systems, the main contributing factor to $\mathrm{CO}_{2}$ emissions is related to the nature and composition of the activating solution [5]. The grinding process of BFS and OBA must be taken into account for the environmental evaluation of the OBA/BFS soil-compacted blocks. Grinding involves relatively low energy use $[7,42]$ when preparing cement and, therefore, low $\mathrm{CO}_{2}$ emissions. Values related to the $\mathrm{CO}_{2}$ emission in the preparation of a ton of soil/OPC ( $10 \%$ of binder) and a ton of soil/OBA+BFS are summarized in Table 6. Gate-to-gate procedure was established, analyzing only the value added process of selection/use of raw materials. If we bear in mind that fabrication of OPC entails 0.907 tons of $\mathrm{CO}_{2}$ emissions per ton, $\mathrm{CO}_{2}$ emissions per ton of stabilized soil is 0.082 tons. For OBA, the $\mathrm{CO}_{2}$ that derives from the grinding process is calculated; for BFS, apart from the grinding contribution, the environmental emission factor (EF) must be taken into account [43]. For each ton of OPC-stabilized soil, $82.5 \mathrm{~kg}$ of $\mathrm{CO}_{2}$ are emitted; interestingly, for each ton of OBA/BFS-stabilized soil, there are $3.3 \mathrm{~kg}$ of $\mathrm{CO}_{2}$. This means a reduction of $96 \%$ in the $\mathrm{CO}_{2}$ associated with the final product in component terms, except soil.

Table 6. Energy parameters and $\mathrm{CO}_{2}$ emission related to the preparation of soil/OPC and soil/OBA+BFS systems.

\begin{tabular}{ccccccc}
\hline Parameter & Energy & OPC & OBA & BFS & Soil/OPC * & Soil/OBA+BFS $^{\#}$ \\
\hline $\mathrm{CO}_{2}$ emission $(\mathrm{kg} / \mathrm{ton})$ & & 0.907 & & 0.0192 & & \\
$\mathrm{CO}_{2}$ emission $(\mathrm{kg} / \mathrm{kWh})$ & 0.272 & & 35.4 & 35.4 & & \\
$\begin{array}{c}\text { Grinding process }(\mathrm{kWh} / \mathrm{ton}) \\
\mathrm{CO}_{2} \text { emission }(\mathrm{kg} / \mathrm{ton})\end{array}$ & & & & & 82.5 & 3.3 \\
\hline & $* 10 \%$ OPC in respect to soil; ${ }^{*} 10 \%$ BFS and $4 \%$ OBA in respect to soil.
\end{tabular}

One practical aspect must be taken into account: alkali-activated cement is usually a two-component (two-part) system and presents difficulties with handling caustic, corrosive and dangerous reagents (alkali hydroxides and/or silicates) when putting into practice this technology within the same scope as OPC [44]. For this reason, many researchers are showing much interest in developing one-part alkali-activated cements ("just add water" cement). The OBA/BFS system is a good candidate for producing one-part cement: a dry mixture is prepared by mixing both ground 
solids: the solid activator (OBA) with the precursor (BFS). Alternately, the co-grinding of OBA and BFS can be carried out to synthesize one-part cement. Additionally, these construction material types have a promising future in developing countries as they involve lower economic and environmental costs, and also contribute to Sustainable Development Goal number 13 (Climate Action).

\section{Conclusions}

The following conclusions can be summarized:

(a) The energetic valorization of OS yields alkaline ash, known as OBA, which presents a sum of $\mathrm{CaO}$ and $\mathrm{K}_{2} \mathrm{O}$ higher than $75 \%$ per mass.

(b) Dolomitic soil stabilization was conducted by adding $10 \%$ BFS, $4 \%$ OBA and $8 \%$ water with excellent compressive strength $(\mathrm{Rc}=27.8 \mathrm{MPa})$ for the $40 \mathrm{~mm}$ cubic specimens obtained at 120 curing days.

(c) The cementing gel formed by the reaction of OBA and BFS was characterized by thermogravimetry: the identification of the decomposition peaks in DTG curves showed the formation of C-S-H, C-A-S-H and hydrotalcite phases.

(d) The FESEM study revealed the formation of the cementing gel-binding calcite and dolomite particles of soil: the chemical composition of the gel revealed the presence of magnesium and potassium and the formation of the $\mathrm{C}(\mathrm{K}, \mathrm{M})-\mathrm{A}-\mathrm{S}-\mathrm{H}$ gel.

(e) The OBA/BFS soil-compacted blocks had a higher water absorption rate than the corresponding OPC ones, which is disadvantageous behavior in durability terms. However, the water strength coefficient for the OBA/BFS blocks was 0.70 for the 2-h immersion and 0.74 for the 72 -h immersion, which indicates the strong adhesion of soil particles and the high insolubility of the cementing gel.

(f) If we focus on the material components, the use of $\mathrm{OBA} / \mathrm{BFS}$ cement reduced $\mathrm{CO}_{2}$ emissions by $96 \%$ compared to the OPC soil-compacted blocks: OBA is an excellent activator of BFS from the mechanical and environmental points of view.

(g) The use of OBA as an activator allowed the preparation of one-part BFS-based cement, which is a good characteristic from the practical point of view.

Author Contributions: Conceptualization, J.R., J.M. and J.P.; methodology, J.R., J.M. and J.P.; formal analysis, A.F., L.S. and M.V.B.; investigation, A.F., L.S., J.R., M.V.B. and J.P.; resources, A.F., L.S. and J.R.; writing-original draft preparation, J.P. and J.R.; writing—review and editing, J.M. and M.V.B.; visualization, A.F., J.R. and M.V.B.; supervision, J.M. and J.P.; project administration, J.P.; funding acquisition, J.M. All authors have read and agreed to the published version of the manuscript.

Funding: This research was funded by the Spanish Government and FEDER funds (MINECO/FEDER-Project RTI2018-09612-B-C21).

Acknowledgments: The authors would like to thank Almazara Candela, Pavasal and Cementval for supplying the raw materials, and the Electronic Microscopy Service at the UPV.

Conflicts of Interest: The authors declare no conflict of interest.

\section{References}

1. Van Damme, H.; Houbenc, H. Earth concrete. Stabilization revisited. Cem. Concr. Res. 2018, 114, 90-102. [CrossRef]

2. Menchaca-Ballinas, L.E.; Escalante-Garcia, J.I. Low $\mathrm{CO}_{2}$ emission cements of waste glass activated by $\mathrm{CaO}$ and NaOH. J. Clean. Prod. 2019, 239, 117992. [CrossRef]

3. Basha, E.A.; Hashim, R.; Mahmud, H.B.; Muntohar, A.S. Stabilization of residual soil with rice husk ash and cement. Cons. Build. Mat. 2005, 19, 448-453. [CrossRef]

4. Rahgozar, M.A.; Saberian, M.; Li, J. Soil stabilization with non-conventional eco-friendly agricultural waste materials: An experimental study. Trans. Geotech. 2018, 14, 52-60. [CrossRef] 
5. Payá, J.; Agrela, F.; Rosales, J.; Martín Morales, M.; Borrachero, M.V. Application of alkali-activated industrial waste. In New Trends in Eco-Efficient and Recycled Concrete; De Brito, J., Agrela, F., Eds.; Woodhead Publishing: Duxford, UK, 2019; pp. 357-424.

6. Sisol, M.; Kudelas, D.; Marcin, M.; Holub, T.; Varga, P. Statistical Evaluation of Mechanical Properties of Slag Based Alkali-Activated Material. Sustainability 2019, 11, 5935. [CrossRef]

7. Mellado, A.; Catalán, C.; Bouzón, N.; Borrachero, M.V.; Monzó, J.M.; Payá, J. Carbon footprint of geopolymeric mortar: Study of the contribution of the alkaline activating solution and assessment of an alternative route. RSC Adv. 2014, 4, 23846-23852. [CrossRef]

8. Tchakouté, H.K.; Rüscher, C.H.; Kong, S.; Ranjbar, N. Synthesis of sodium waterglass from white rice husk ash as an activator to produce metakaolin-based geopolymer cements. J. Build. Eng. 2016, 6, 252-261. [CrossRef]

9. Tchakouté, H.K.; Rüscher, C.H.; Hinsch, M.; Djobo, N.Y.; Kamseu, E.; Leonelli, C. Utilization of sodium waterglass from sugar cane bagasse ash as a new alternative hardener for producing metakaolin-based geopolymer cement. Chem. Erde Geochem. 2017, 77, 257-266. [CrossRef]

10. Moraes, J.C.B.; Font, A.; Soriano, L.; Akasaki, J.L.; Tashima, M.M.; Monzó, J.; Borrachero, M.V.; Payá, J. New use of sugar cane straw ash in alkali-activated materials: A silica source for the preparation of the alkaline activator. Cons. Build. Mat. 2018, 171, 611-621. [CrossRef]

11. Font, A.; Soriano, L.; Reig, L.; Tashima, M.M.; Borrachero, M.V.; Monzó, J.; Payá, J. Use of residual diatomaceous earth as a silica source in geopolymer production. Mat. Lett. 2018, 223, 10-13. [CrossRef]

12. Samarakoon, M.H.; Ranjith, P.G.; Duan, W.H.; De Silva, V.R.S. Properties of one-part fly ash/slag-based binders activated by thermally-treated waste glass/ $\mathrm{NaOH}$ blends: A comparative study. Cem. Concr. Comp. 2020, 112, 103679. [CrossRef]

13. Zhaoa, X.; Liua, C.; Wanga, L.; Zuob, L.; Zhub, Q.; Mab, W. Physical and mechanical properties and micro characteristics of fly ash based geopolymers incorporating soda residue. Cem. Concr. Comp. 2019, 98, 125-136. [CrossRef]

14. Bilginer, A.; Canbek, O.; Erdoğan, S.T. Activation of blast furnace slag with soda production waste. J. Mater. Civ. Eng. 2020, 32, 04019316. [CrossRef]

15. Ban, C.; Ken, P.W.; Ramli, M. Mechanical and durability performance of novel self-activating geopolymer mortars. Proc. Eng. 2017, 171, 564-571. [CrossRef]

16. Peys, A.; Rahier, H.; Pontikes, Y. Potassium-rich biomass ashes as activators in metakaolin-based inorganic polymers. Appl. Clay Sci. 2016, 119, 401-409. [CrossRef]

17. Soriano, L.; Font, A.; Tashima, M.M.; Monzó, J.; Borrachero, M.V.; Payá, J. One-part blast furnace slag mortars activated with almond-shell biomass ash: A new 100\% waste-based material. Mat. Lett. 2020, 272, 127882. [CrossRef]

18. Abdullah, H.H.; Shahin, M.A.; Walske, M.L. Review of fly-ash-based geopolymers for soil stabilisation with special reference to clay. Geosciences 2020, 10, 249. [CrossRef]

19. Cristelo, N.; Miranda, T.; Oliveira, D.V.; Rosa, I.; Soares, E.; Coelho, P.; Fernandes, L. Assessing the production of jet mix columns using alkali activated waste based on mechanical and financial performance and $\mathrm{CO}_{2}$ (eq) emissions. J. Clean. Prod. 2015, 102, 447-460. [CrossRef]

20. Font, A.; Soriano, L.; Moraes, J.C.B.; Tashima, M.M.; Monzó, J.; Borrachero, M.V.; Payá, J. A 100\% waste-based alkali-activated material by using olive-stone biomass ash (OBA) and blast furnace slag (BFS). Mat. Lett. 2017, 203, 46-49. [CrossRef]

21. Pinheiro, S.M.M.; Font, A.; Soriano, L.; Tashima, M.M.; Monzó, J.; Borrachero, M.V.; Payá, J. Olive-stone biomass ash (OBA): An alternative alkaline source for the blast furnace slag activation. Cons. Build. Mat. 2018, 178, 327-338. [CrossRef]

22. American Society for Testing and Materials. ASTM STP479. In Special Procedures for Testing Soil and Rock for Engineering Purposes; American Society for Testing and Materials: West Conshohocken, PA, USA, 1970.

23. UNE 103501. In Geotechnic. Compactation Test. Modified Proctor; AENOR: Madrid, Spain, 1994. (In Spanish)

24. UNE-EN 196-1. In Methods of Testing Cement_Part 1: Determination of Strength; AENOR: Madrid, Spain, 2018. (In Spanish)

25. UNE 41410. In Compressed Earth Blocs for Walls and Partitions. Definitions, Specifications and Test Methods; AENOR: Madrid, Spain, 2008. (In Spanish)

26. NTC 5324. In Ground Blocks Cement for Walls and Division. Definitions, Specifications. Test Methods. Conditions of Delivery; ICONTEC: Bogota, Colombia, 2004. (In Spanish) 
27. Alonso, M.M.; Gascó, C.; Martín Morales, M.; Suárez-Navarro, J.A.; Zamorano, M.; Puertas, F. Olive biomass ash as an alternative activator in geopolymer formation: A study of strength, radiology and leaching behaviour. Cem. Concr. Comp. 2019, 104, 103384. [CrossRef]

28. Vossen, P. Olive Oil: History, Production, and Characteristics of the World's Classic Oils. Hort. Sci. 2007, 42, 1093-1100. [CrossRef]

29. Roig, A.; Cayuela, M.L.; Sánchez-Monedero, M.A. An overview on olive mill wastes and their valorisation methods. Waste Manag. 2006, 26, 960-969. [CrossRef]

30. García Martín, J.F.; Cuevas, M.; Feng, C.; Álvarez-Mateos, P.; Torres-García, M.; Sánchez, S. Energetic Valorisation of Olive Biomass: Olive-Tree Pruning, Olive Stones and Pomaces. Processes 2020, 8, 511.

31. Cosa, J.; Soriano, L.; Borrachero, M.V.; Payá, J.; Monzó, J. Stabilization of soil by means alternative alkali-activated cement prepared with spent FCC catalyst. Appl. Ceram. Technol. 2020, 17, 190-196. [CrossRef]

32. Xing, J.; Zhao, Y.; Qiu, J.; Sun, X. Microstructural and mechanical properties of alkali activated materials from two types of blast furnace slags. Materials 2019, 12, 2089. [CrossRef] [PubMed]

33. Burciaga-Díaz, O.; Escalante-García, J.I. Structure, mechanisms of reaction, and strength of an alkali-activated blast-furnace slag. J. Am. Ceram. Soc. 2013, 96, 3939-3948. [CrossRef]

34. Gunasekaran, S.; Anbalagan, G. Thermal decomposition of natural dolomite. Bull. Mater. Sci. 2007, 30, 339-344. [CrossRef]

35. Walkley, B.; Rackel San Nicolas, R.; Sani, M.; Rees, G.J.; Hanna, J.H.; van Deventer, J.S.J.; Provis, J.L. Phase evolution of C-(N)-A-S-H/N-A-S-H gel blends investigated via alkali-activation of synthetic calcium aluminosilicate precursors. Cem. Concr. Res. 2016, 89, 120-135. [CrossRef]

36. Puertas, F.; Palacios, M.; Manzano, H.; Dolado, J.S.; Rico, A.; Rodríguez, J. A model for the C-A-S-H gel formed in alkali-activated slag cements. J. Eur. Ceram. Soc. 2011, 31, 2043-2056. [CrossRef]

37. Ortega-Zavala, D.E.; Santana-Carrillo, J.L.; Burciaga-Díaz, O.; Escalante-García, J.I. An initial study on alkali activated limestone binders. Cem. Concr. Res. 2019, 120, 267-278. [CrossRef]

38. Kinuthia, J.M. The durability of compressed earth-based masonry blocks, In Eco-Efficient Masonry Bricks and Blocks; Pacheco-Torgal, F., Lourenço, P.B., Labrincha, J.A., Kumar, S., Chindaprasirt, P., Eds.; Woodhead Publishing: Duxford, UK, 2015; pp. 393-421.

39. Houben, H.; Verney, P.E.; Maini, S.; Webb, D.J.T. Compressed Earth Bricks. SELECTION of Production Equipment; CDI: Brussels, Belgium, 1989.

40. Guettala, A.; Abibsi, A.; Houari, H. Durability study of stabilized earth concrete under both laboratory and climatic conditions exposure. Cons. Build. Mater. 2006, 20, 119-127. [CrossRef]

41. Salim, R.W.; Ndambuki, J.M.; Adedokun, D.A. Improving the bearing strength of sandy loam soil compressed earth block bricks using sugarcane bagasse ash. Sustainability 2014, 6, 3686-3696. [CrossRef]

42. De Brito, J.; Kurda, R. The past and future of sustainable concrete: A critical review and new strategies on cement-based materials. J. Clean. Prod. 2020; 123558, in press.

43. Font, A.; Soriano, L.; Tashima, M.M.; Monzó, J.; Borrachero, M.V.; Payá, J. One-part eco-cellular concrete for the precast industry: Functional features and life cycle assessment. J. Clean. Prod. 2020, 269, 122203. [CrossRef]

44. Luukkonen, T.; Abdollahnejad, Z.; Yliniemi, J.; Kinnunen, P.; Illikainen, M. One-part alkali-activated materials: A review. Cem. Concr. Res. 2018, 103, 21-34. [CrossRef]

Publisher's Note: MDPI stays neutral with regard to jurisdictional claims in published maps and institutional affiliations.

(C) 2020 by the authors. Licensee MDPI, Basel, Switzerland. This article is an open access article distributed under the terms and conditions of the Creative Commons Attribution (CC BY) license (http://creativecommons.org/licenses/by/4.0/). 